\title{
Teacher Satisfaction in Spain with the European Higher Education Area: Arts and Humanities*
}

\section{Satisfacción del profesorado en España con el Espacio Europeo de Educación Superior: Artes y Humanidades}

\author{
Raúl Quevedo-Blasco ${ }^{a}$ \\ Universidad de Granada, España \\ Gualberto Buela-Casal \\ Universidad de Granada, España
}

a Correspondence author. Email: rquevedo@ugr.es

How to cite: Quevedo-Blasco, R., \& Buela-Casal, G. (2019). Teacher satisfaction in Spain with the European Higher Education Area: Arts and Humanities. Universitas Psychologica, 18(5), 1-16. htt ps://doi.org/10.11144/Javeriana.upsy18-5.tsse

\begin{abstract}
In Spain reforms to university educational policy have been made in order to adapt to the European Higher Education Area (EHEA). Therefore, the objective of this study was to find out the level of satisfaction of Arts and Humanities university teaching staff towards the implementation of the EHEA. It is a population-based, descriptive study using a cross-sectional survey with a probability sample. The sample consisted of 1605 Spanish teachers of Arts and Humanities from public universities (with an average age of 48 years, of which $52 \%$ were women and $48 \%$ men). They were applied an ad hoc survey $(\alpha=0.82)$ consisting of questions (grouped into eight sections) about the degree of satisfaction towards different aspects of the EHEA. In the results can be observed that teachers are not completely satisfied with the way in which educational institutions have adapted university education to the EHEA and they have identified certain needs that limit the quality of Arts and Humanities teaching. In conclusion, the most of teachers thought that the implementation of the EHEA could be improved, although a small percentage believed that it had not been implemented correctly.

Keywords

Bologna process; Higher Education; satisfaction; teachers; Arts and Humanities.
\end{abstract}

\section{RESUMEN}

En España se han hecho reformas en la política educativa universitaria con el objetivo de adaptarse al Espacio Europeo de Educación Superior (EEES). Por ello, la finalidad del estudio fue conocer la satisfacción del profesorado universitario de Artes y Humanidades hacia la implantación del EEES. Es un estudio descriptivo de poblaciones mediante encuesta con muestreo probabilístico, tipo transversal. La muestra estuvo compuesta por 1605 profesores españoles de Artes y Humanidades de universidades públicas (con una edad media de 48 años, de los cuales $52 \%$ eran mujeres y $48 \%$ hombres). Se les aplicó una encuesta elaborada ad hoc $(\alpha=0.82)$ formada por preguntas (agrupadas en ocho secciones) sobre el grado de satisfacción hacia diferentes aspectos del EEES. En los resultados se puede observar que los profesores no están completamente satisfechos con el modo en que las instituciones educativas han adaptado las enseñanzas universitarias al EEES y han detectado necesidades que limitan la calidad 
de las enseñanzas de Artes y Humanidades. En conclusión, la mayoría de los profesores creen que la aplicación del EEES se podría mejorar, aunque un pequeño porcentaje informan que no se ha aplicado correctamente.

Palabras clave

Proceso de Bolonia; Educación Superior; satisfacción; profesorado; Artes y Humanidades.

Spain joined the European Higher Education Area (EHEA) with the Bologna Declaration (1999), committing itself to the adoption of a comparable degree system and the promotion of student and teacher mobility. Furthermore, during the Lisbon European Council (2000) a strategy was formed towards the creation of the European Research Area (ERA) in order to facilitate the mobility of researchers and coordinate research policies in Europe. In Bucharest is passed the "2020 Mobility Strategy: Better Learning Strategy", in which it was established that national and institutional strategies for internationalisation and mobility in Higher Education (Ministerial Conference Bucharest, 2012). All this is reflected in studies on resources will help researchers (v.gr., Palma i Muñoz, 2019), the research of Spanish public universities (v.gr., Buela-Casal, GuillénRiquelme, Díaz-Román, Carneiro-Barrera, \& Quevedo-Blasco, 2019; Buela-Casal, GuillénRiquelme, Ramiro-Sánchez, \& Quevedo-Blasco, 2017), the analysis of doctoral theses (v.gr., Carneiro-Barrera, Ruiz-Herrera, \& Díaz-Román, 2019), and the university teaching innovation experiences (v.gr., Cano García, Pons Seguí, \& Lluch Molins, 2018). Therefore, an initiative aimed at modernizing Spanish universities was developed. This initiative was called University Strategy 2015 (Ministerio de Educación, 2011) and was created to facilitate consolidation between the EHEA and the ERA (see as well, Ministerio de Educación, Cultura y Deporte, 2016). The rest of the EHEA member countries also established measures to adapt to the Bologna Plan, showing progression in their university educational policy.

In order to promote employability and competitiveness, Royal Decree 1044/2003 was elaborated in Spain, regulating the European
Diploma Supplement. The European Credit Transfer System (ECTS) and the grading system were regulated with Royal Decree 1125/2003. In the system prior to the EHEA in Spain, a credit was made up of ten teaching hours by the student, whilst the ECTS is equivalent to 25-30 hours of work by the student. The adoption of Royal Decree 1393/2007 established teaching structure and the verification and accreditation of qualifications. The three-cycle system was implemented (Degree, Master, and Doctorate) and new syllabuses created were evaluated by the National Agency for Quality Assurance and Accreditation (Agencia Nacional de Evaluación de la Calidad y Acreditación, ANECA). According to this decree, previous qualifications (the three-year Diploma and fiveyear Degree [Licenciatura]) are substituted by the new Degree [Grado], in which 240 ECTS have to be passed in four years. As for Master programs, studies will have between 60 and 120 ECTS (from one to two years). Besides this, Royal Decree 99/2011 states that doctoral studies will have a duration of three years full-time, and also regulates the creation of Doctoral Schools.

The Bologna process has aroused the interest of Spanish researchers in analyzing aspects such as the adaptation of qualifications to the EHEA (Cañadas, Santos-Pastor, \& Castejón, 2018), teaching and learning methodologies (Gaebel \& Zhang, 2018; Vargas \& Montero, 2016), and competence based assessment (Cano García \& Fernández Ferrer, 2016; Leví Orta, \& Ramos Méndez, 2012; Martínez Clares \& González Morga, 2018). Since the introduction of the EHEA the teaching methodology encouraged involves the student taking on a more active role and the teacher taking the role of guide/mediator. The implementation of the ECTS and the emergence of competencebased learning have prompted this change of methodology (v.gr., Bezanilla, García Olalla, Paños Castro, \& Poblete Ruiz, 2019; Martín \& García García, 2018). Therefore, students should abandon the passive role adopted previously and become the key players in search of their own knowledge and competences (v.gr., Carrión-Martínez, Fernández-Martínez, Pérez- 
Fuentes, \& Gázquez-Linares, 2018; Martínez Clares \& González Morga, 2019; MorenoMurcia, Pintado, Huéscar, \& Marzo, 2018; Rodríguez-Fernández et al., 2016; Sandoval \& Pérez-Zapata, 2017).

In the evaluation of attitude of Spanish university teachers towards the Bologna Process, in the study by Fernández Díaz, Carballo Santaolalla and Galán González (2010) detected negative attitudes towards the reform at the end of the period of change, related to a lack of information and uncertainty, although they found that the Humanities teachers are more optimistic than those from other fields of knowledge with regard to updating teaching methods. Therefore, once finalized the period of adapting qualifications to the EHEA and the recent implementation of measures to achieve consolidation in Spanish universities, it is necessary to find out the opinion of all those involved in this change. This educational reform has not only implied certain structural changes in Higher Education, but also a new way of conceiving education and the way in which the professor teaches. This new educational paradigm implies that the teacher abandons the traditional role he has been assuming until now, ceasing to be only a transmitter of basic knowledge of the discipline to become a mediator in the teaching-learning process, in which supervision and student tutoring are essential (Canet Vélez \& Violant Holz, 2014). For all the above, the knowledge of teacher satisfaction regarding this institutionalization process is fundamental since there has been a historical fact in Europe in the educational field.

Given the lack of research carried out in the Arts and Humanities field, the aim of this study is to evaluate the satisfaction of the Spanish university teachers of the aforementioned field of knowledge towards the implementation of the Bologna Process. To achieve this objective, it is necessary to evaluate the main aspects in which teachers have been involved in their adaptation to the EHEA (both in undergraduate and postgraduate degree programmes). For this, it is necessary to use a survey (as it is the format that best suits the type of questions required) with questions oriented to general and institutional issues related to the EHEA, variables related to teaching, research and management, issues related to coordination, organization and teaching resources, the teaching-learning process, the methodology used in the university after the implementation of the EHEA, variables related to the evaluation of teaching and training aspects, among others.

\section{Method}

\section{Participants}

In total, 1,605 teachers participated in this study, from qualifications belonging to Arts and Humanities in Spanish public universities, with an average age of 48 years $(S D=9)$, of which $52 \%$ were women and $48 \%$ men (the faculty they belong to can be seen in Table 1). The average years of teaching experience is 19 (SD $=11$ ) and the majority (36\%) has not received a six-year bonus (a productivity bonus offered to permanent university teachers for six years of research activity). The universities with a higher participation can be seen in Table 2 .

\section{Table 1}

Percentage of Arts and Humanities teachers according to their professional category

\begin{tabular}{lr}
\hline \multicolumn{1}{c}{ Category } & \multicolumn{1}{c}{$\%$} \\
\hline Senior University staff & 16.2 \\
University staff & 45.8 \\
Senior University School staff & 0.4 \\
University School staff & 1.9 \\
Non-permanent staff & 33.1 \\
\hline
\end{tabular}


Table 2

Percentage of Arts and Humanities teachers with a higher participation in the study according to their institutional affiliation

\begin{tabular}{ll}
\hline \multicolumn{1}{c}{ University } & $\%$ \\
\hline Barcelona & 8.7 \\
Complutense de Madrid & 6.4 \\
Salamanca & 4.6 \\
Granada & 4.4 \\
Sevilla & 4.4 \\
Autónoma de Barcelona & 4.3 \\
Autónoma de Madrid & 4.3 \\
Santiago de Compostela & 4.2 \\
Castilla La Mancha & 3.5 \\
Alicante & 3.4 \\
\hline
\end{tabular}

Note:In this list only institutions with a participation percentage of over 3.2 per cent appear. The universities with the same participation percentage have been ordered alphabetically.

Materials and instrument

- Survey regarding the satisfaction of Spanish University Teaching Staff towards EHEA adaptation (Ariza, Quevedo-Blasco, Ramiro, \& Bermúdez, 2013), made up of 65 mixed questions (with Likert scale and multiple-choice questions and a final open-ended one) divided into seven sections (related to teaching staff data, the EHEA implementation process on a general and institutional level, tasks of the teaching staff, methodology and the teaching-learning process, student assessment, teacher training, and coordination, organization and center resources), and a final section (comments and/ or suggestions) for any possible suggestions the teaching staff may have (eight sections in total). The Cronbach alpha coefficient for the evaluation of teaching staff satisfaction was 0.82 .

- Database with the email of the selected teaching staff.

- IT program for creating and sending surveys.
Design and procedure

It is a population-based, descriptive study using a cross-sectional survey with a probability sample. Firstly, updated information (based on the legislation and literature analyzed) regarding the implementation of the EHEA was found in national and international databases in order to formulate the survey questions ad hoc. The survey was evaluated using the judgment of experts, with experience in teaching and in the adaptation process of degrees to the EHEA (in order to verify the suitability of either the thematic blocks or the questions). After the evaluation and following the recommendations of the experts, some items of the questionnaire were reformulated, but for their suitability, the same number of questions from the initial version was maintained. Finally, it was checked that everything was correct and that the application was working properly. The sample was selected with a $97 \%$ confidence level and an estimation error of $3 \%$. An invitation to participate in the study was sent to the email of the selected teachers, including survey information, along with a link through which each subject could access the questions using an assigned personal password in order to answer them individually (only once). Participant anonymity was guaranteed and the Spanish data protection law was applied (guaranteeing the confidentiality of the data). In addition, there are no ethical implications for participants.

\section{Results}

\section{General and institutional aspects}

In total, $46 \%$ of teachers thought that the adaptation of Spanish Higher Education to the EHEA could be improved, followed by those that considered that the process has not been implemented correctly (44\%). Besides, $49 \%$ doubted the benefits of the changes in Spanish universities and $29 \%$ stated that the modifications would not be positive for Higher Education. It is worth mentioning that almost 40 
$\%$ found it difficult to adapt their lesson planning (see Table 3). On the other hand, $60 \%$ found it easy to adapt to the EHEA, followed by $20 \%$ who were not prepared for the change in the system. In Figure 1 it can be observed that the majority of teachers showed a moderate satisfaction towards the new qualifications structure, the ECTS credit and qualifications system, the European Diploma Supplement (EDS), along with teaching accreditation. Despite this, $41 \%$ would return to the old system, compared to $40 \%$ that prefers the EHEA.

\section{Table 3}

Percentage of Arts and Humanities teachers according to the level of effort dedicated to the adaptation of lesson planning

\begin{tabular}{lr}
\hline \multicolumn{1}{c}{ Level } & \multicolumn{1}{c}{$\%$} \\
\hline None & 2.3 \\
Few & 6.6 \\
Moderate & 27.3 \\
Fairly high & 39.8 \\
High & 23.8 \\
\hline
\end{tabular}

Figure 1.

Percentage of Arts and Humanities teachers according to the level of satisfaction towards different aspects of the EHEA.

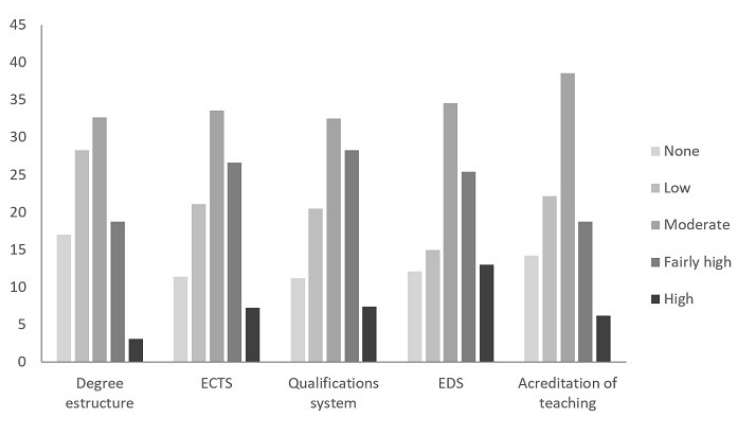

Note: ECTS = European Credit Transfer System; EDS = European Diploma Supplement.

Approximately $31 \%$ of the teaching staff thought that the quality of Higher Education would increase only slightly, followed by those who believed that it would do so moderately (29\%) (see Table 4). The percentages regarding the duration they consider most appropriate for degree studies can be seen in Figure 2. Regarding official research masters, almost $52 \%$ were of the opinion that they should be 120 ECTS (two years). Besides, $47 \%$ maintained having received enough information regarding the Bologna Process, compared to $27 \%$ who considered having received very little. Limitations observed on a general and institutional level, along with possible solutions, can be observed in Table 5 .

\section{Table 4}

Percentage of Arts and Humanities teachers according to their opinion regarding how much Higher Education will improve with the European Higher Education Area

\begin{tabular}{lr}
\hline \multicolumn{1}{c}{ Level } & \multicolumn{1}{c}{$\%$} \\
\hline None & 23.8 \\
Few & 30.8 \\
Moderate & 29.0 \\
Fairly high & 14.5 \\
High & 1.8 \\
\hline
\end{tabular}


Figure 2.

Percentage of Arts and Humanities teachers according to the length they consider appropriate for Degree studies

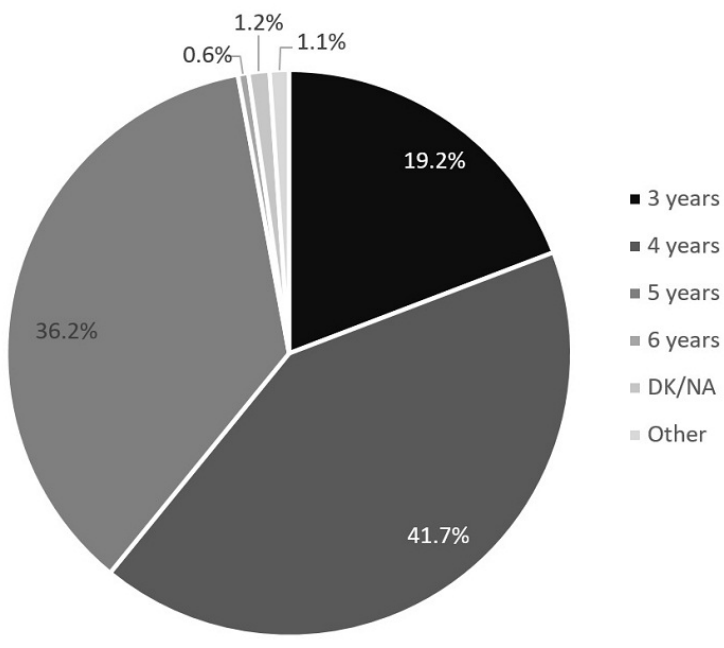

Table 5

General and institutional limitations and possible solutions suggested by Arts and Humanities teachers to improve the European Higher Education Area

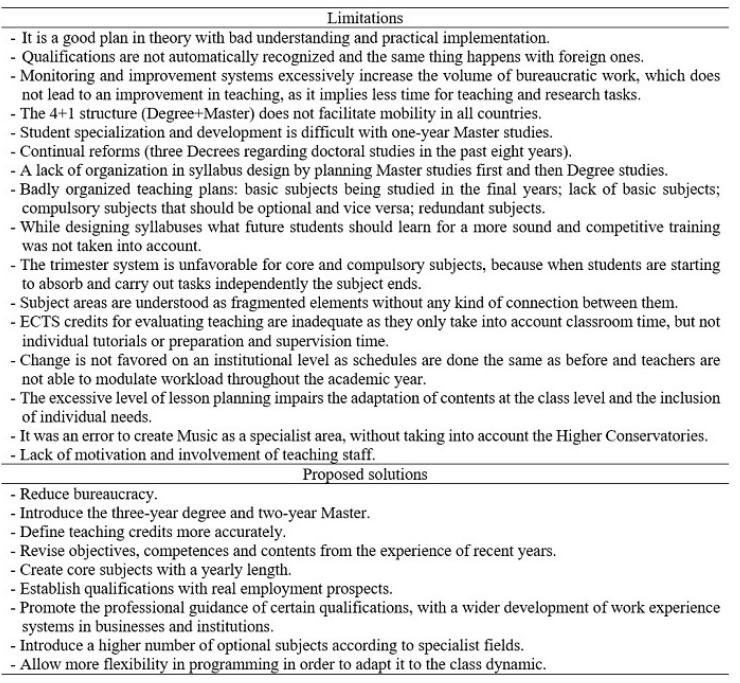

\section{Tasks of Spanish Teaching Staff}

For the majority of the Arts and Humanities teaching staff, teaching and research tasks are priorities (see Figure 3). Teaching staff pointed out that their teaching planning is quite well adjusted to the EHEA (see Table 6). In Table 7 the level of effort required to carry out teaching functions can be observed. At present, $54 \%$ need more time for preparation, followed by $30 \%$ who take the same time as they did before the process.

\section{Figure 3.}

Percentage of Arts and Humanities teachers according to the priority assigned to their attributed tasks

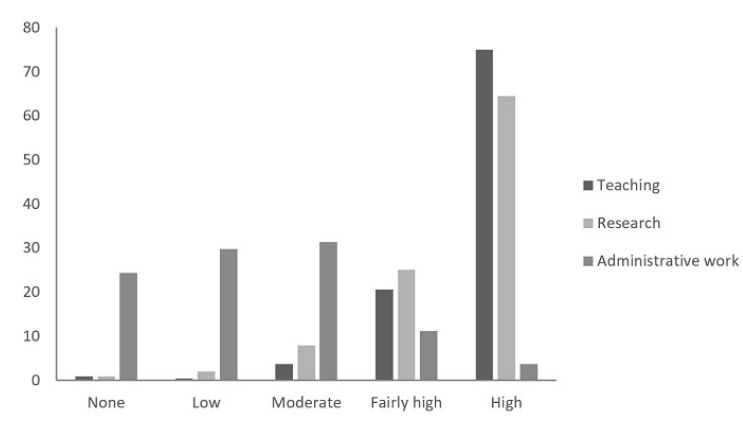

Table 6

Percentage of Arts and Humanities teachers according to the level which their teaching planning is adapted to the European Higher Education Area

\begin{tabular}{lr}
\hline \multicolumn{1}{c}{ Level } & \multicolumn{1}{c}{$\%$} \\
\hline None & 1.1 \\
Few & 3.3 \\
Moderate & 15.0 \\
Fairly high & 50.9 \\
High & 29.5 \\
\hline
\end{tabular}

\section{Table 7}

Percentage of Arts and Humanities teachers according to the level of effort required for carrying out teaching related tasks

\begin{tabular}{lcccccccc}
\hline $\begin{array}{c}\text { Level of } \\
\text { effort }\end{array}$ & $\begin{array}{c}\text { Teach. } \\
\text { role }\end{array}$ & Theory & Practical & Sem. & Sup. & Tutorial & Assess. & Coor. \\
\hline None & 9.6 & 9.3 & 7.2 & 9.2 & 6.9 & 9.1 & 4.9 & 5.9 \\
Low & 13.2 & 17.2 & 11.2 & 12.0 & 11.4 & 15.3 & 8.1 & 10.9 \\
Moderate & 32.2 & 33.9 & 25.8 & 31.0 & 25.7 & 29.7 & 24.6 & 29.7 \\
Fairly high & 28.7 & 26.6 & 31.6 & 29.2 & 28.3 & 25.2 & 29.7 & 28.7 \\
High & 16.2 & 12.8 & 23.9 & 18.4 & 27.4 & 20.5 & 32.4 & 24.6 \\
\hline
\end{tabular}

Note:Teach. role $=$ Role of teacher; Sem. $=$ Seminars; Sup. $=$ Supervision; Assess. $=$

Assessment; Coor. $=$ Teaching coordination . Source: own work. 
Furthermore, attitudes towards the ERA were positive amongst $59 \%$ of teachers, followed by $24 \%$ who had a negative vision. Since joining the EHEA 53\% declared not having dedicated more time to research, although they would have liked to, while $28 \%$ stated that they dedicate the same time as before and $67 \%$ would prefer to dedicate less hours to administration. With regard to doctoral studies, $32 \%$ said they prefer the new postgraduate system (Master and Doctorate) and $31 \%$ would prefer the traditional system. Regarding the doctoral thesis, $80 \%$ would choose the traditional thesis and only $8 \%$ declared that they prefer the collection of scientific articles. With regard to financing the thesis in a period of three years, approximately $52 \%$ considered it to be possible, depending on the research area, followed by those who did not find it viable (26\%). Likewise, almost $71 \%$ did not believe that thesis quality would improve with the new doctoral organization. Opinion regarding Doctoral Schools can be seen in Figure 4. The teachers also pointed out limitations and proposed possible solutions to improve teaching and research in the EHEA context (see Table 8).

\section{Figure 4.}

Percentage of Arts and Humanities teachers according to their attitude towards Doctoral Schools

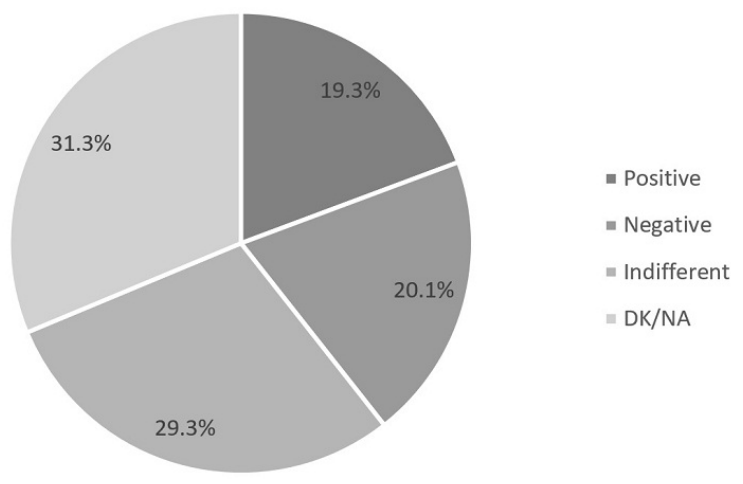

Table 8

Teaching and research limitations and possible solutions suggested by Arts and Humanities teachers for the improvement of the European Higher Education Area

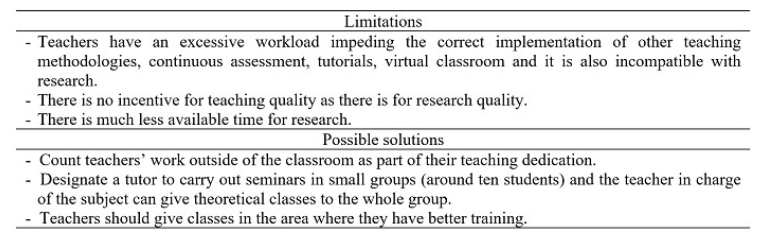

\section{Methodology and the teaching-learning}

In total, $62 \%$ of teachers said they agree with the teaching and learning methodology in which the teacher acts as a guide/mediator, compared to $21 \%$ who do not agree. However, $48 \%$ stated that they do not think that it increases learning quality. Furthermore, $68 \%$ will not continue to give classes with a predominance of lectures, while $23 \%$ will continue with this method. In Tables 9 and 10 the motivation of students in the search of their own knowledge is illustrated, and also the frequency with which they use tutorials to ask subject queries. Moreover, 41 $\%$ of teachers affirmed that competences are quite well developed in their students (see Table 11). On the other hand, $58 \%$ doubted that the current doctoral system guarantees competence development in doctoral students, followed by 16 \% who chose the "Don't know/No answer (DK/ NA)" option and $13 \%$ who answered yes. In Table 12 the limitations detected by teaching staff in relation to this section can be observed. 
Table 9

Percentage of Arts and Humanities teachers according to the level of motivation of their students towards an active role in their learning

\begin{tabular}{lc}
\hline \multicolumn{1}{c}{ Level } & \multicolumn{1}{c}{$\%$} \\
\hline None & 11.6 \\
Few & 35.8 \\
Moderate & 38.0 \\
Fairly high & 13.1 \\
High & 1.2 \\
\hline
\end{tabular}

Table 10

Frequency with which students assist tutorials according to the Arts and Humanities teachers

\begin{tabular}{lr}
\hline \multicolumn{1}{c}{ Frequency } & \multicolumn{1}{c}{$\%$} \\
\hline Never & 5.9 \\
Little & 49.7 \\
Moderate & 27.4 \\
Fairly high & 12.8 \\
High & 3.9 \\
\hline
\end{tabular}

\section{Table 11}

Level of development of student competences according to the Arts and Humanities teachers

\begin{tabular}{lr}
\hline \multicolumn{1}{c}{ Level } & \multicolumn{1}{c}{$\%$} \\
\hline None & 1.7 \\
Few & 3.8 \\
Moderate & 22.9 \\
Fairly high & 46.1 \\
High & 25.3 \\
\hline
\end{tabular}

\section{Table 12}

Limitations in methodology and in the teaching and learning process and possible solutions suggested by Arts and Humanities teachers for the improvement of the European Higher Education Area

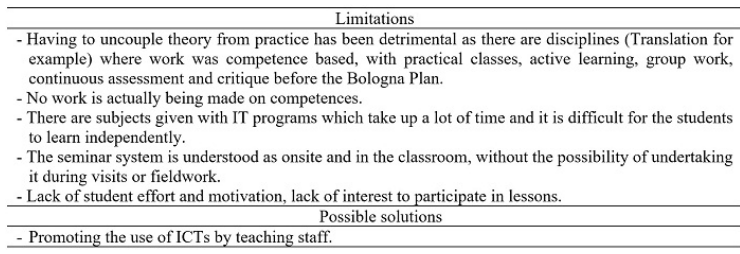

Assessment

In total, $68 \%$ of teachers stated that they prefer an objective and competence based assessment, followed by $13 \%$ who opted for assessment based only on objectives and $9 \%$ based only on competences. Moreover, $54 \%$ declared that they find assessment easy on a practical level, in contrast to $41 \%$ who find it difficult. In Figure 5, the moment in which Arts and Humanities teachers carry out assessment can be observed. The majority opt for evaluating throughout the academic year, both in theory and practical lessons. The level of satisfaction with students' grades after the introduction of the EHEA can be seen in Table 13. In total, $38 \%$ maintained that they were better before the consolidation of the process, followed by $35 \%$ who did not think there have been any changes. In Table 14 requirements regarding assessment processes can be observed. Teachers did not propose any improvements regarding this section. 


\section{Figure 5.}

Percentage of Arts and Humanities teachers according to the moment in which they carry out student assessment

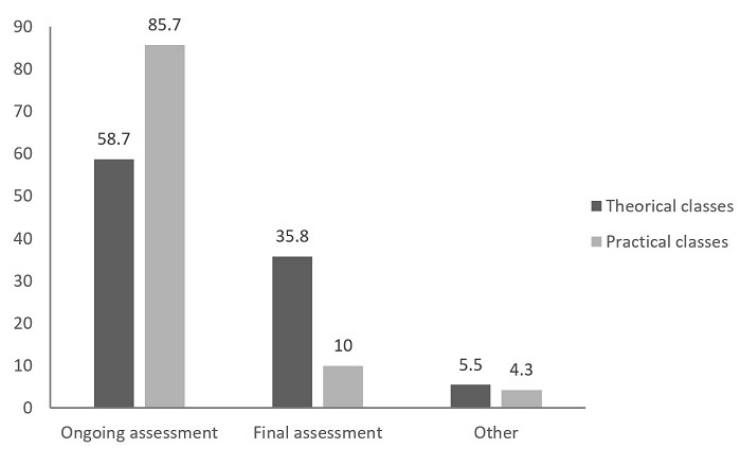

Table 13

Percentage of Arts and Humanities teachers according to their level of satisfaction with students' academic results

\begin{tabular}{lr}
\hline \multicolumn{1}{c}{ Level } & \multicolumn{1}{c}{$\%$} \\
\hline None & 2.9 \\
Few & 12.0 \\
Moderate & 36.7 \\
Fairly high & 39.6 \\
High & 8.6 \\
\hline
\end{tabular}

\section{Table 14}

Limitations in the assessment process suggested by Arts and Humanities teachers for the improvement of the European Higher Education Area

\footnotetext{
- Competence based assessment and individual student attention is very complicated with a high number

of students per class.
- Competence based assessment has not been developed correctly as in the final grade of a subject the breakdown of how each competence has been passed does not appear.

- Continuous assessment does not guarantee the knowledge acquired: it makes passing easy but hinders excellent grades.
}

\section{Training}

Overall, $65 \%$ thought that they have adequate training to give classes in the EHEA context. However, $30 \%$ believed that they are not totally qualified and that they would need to receive further training. Lifelong learning, one of the EHEA principles, is supported by 90 $\%$ of teachers, and $67 \%$ had plans to carry out a temporary stay abroad to improve their knowledge. The limitations detected by teachers in the area of teacher and student training can be seen in Table 15, as well as the suggested improvements.

\section{Table 15}

Training limitations suggested by Arts and Humanities teachers for the improvement of the European Higher Education Area

\begin{tabular}{l} 
Limitations \\
\hline - Teacher training is not adequate, courses are not effective and it is difficult to combine them with teaching \\
and research. \\
- The trainers in charge of the training courses are not qualified to resolve the lack of teacher training or \\
resolve their problems. \\
- Lack of teacher mobility. \\
- Difficulty for teachers to carry out stays abroad (for teaching and research) because of their high teaching \\
worklaad and financial help offered only for long-term stays. \\
- Very low foreign language level amongst teachers. \\
- Students enter university with a very low level, making achieving the proposed objectives more difficult \\
(they are not used to reading, giving a critical opinion, debating, etc.) and teachers find themselves forced \\
to explain matters of general culture (not relevant to the specific training). \\
- Diploma/Degree students had a more solid training than those of the current Degree studies; there are \\
shortages meaning that they are not sufficiently prepared for specialization (Master). \\
- Certain Research Master courses do not prepare students for research work in an appropriate and practical \\
manner. \\
- There is no guarantee that foreign stays carried out by doctoral students will be useful and that students \\
will acquire more knowledge than those that have been in Spain preparing their thesis and research. \\
Possible solutions \\
\hline - Encourage the international exchange of teaching staff. \\
- Establish a University entrance exam, adapted to the field of knowledge chosen by the student. \\
- Demand a higher and more riggoous general training level in order to start tuiversitity studies. \\
- More coordination between training phases (Primary, Secondary and University), introducing habits and \\
skills in the first phases so that they are really achieved when finalizing university studies.
\end{tabular}

Coordination, Student organization and Resources

$51 \%$ stated that there is little coordination with the rest of the teachers of their department, compared to $24 \%$ who maintained that there is a lot of coordination. Furthermore, $69 \%$ declared that the reduction of the ratio of students per classroom is not being applied in their center, although just over half claimed that the average number of students per class is 65 or less. Data regarding the availability of resources in the center can be seen in Figure 6. In Table 16, limitations detected by teaching staff with regard to teacher coordination, student ratio and available resources can be observed, along with possible solutions to overcome these problems. 
Figure 6.

Percentage of Arts and Humanities teachers according to the level of resources received in their center

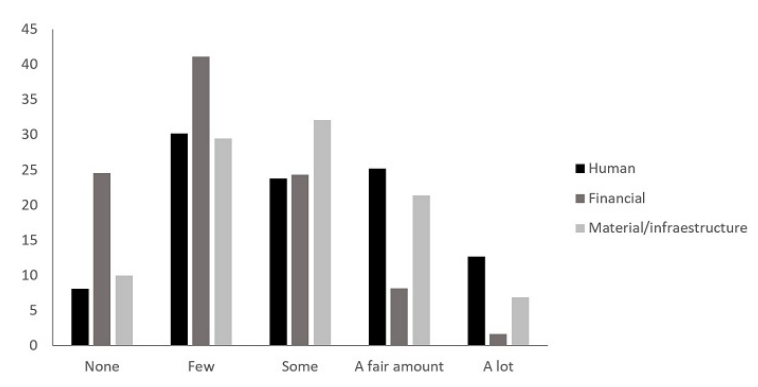

Table 16

Limitations in coordination, organization, resources and possible solutions suggested by Arts and Humanities teachers for the improvement of the European Higher Education Area

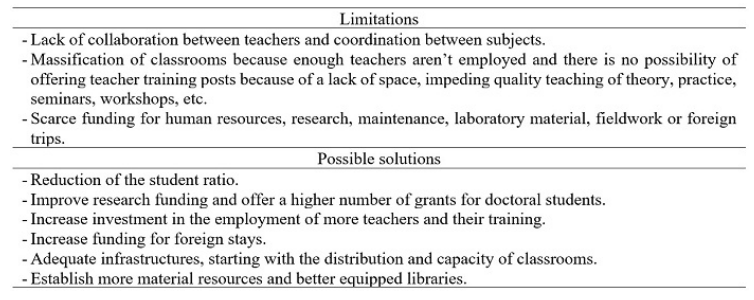

\section{Discussion}

During this study the satisfaction of Arts and Humanities teachers towards the EHEA has been analyzed. According to the results there is a wide range of opinions regarding the development of the process in Spain. The majority of teachers thought that the implementation of the EHEA could be improved, although a small percentage believed that it had not been implemented correctly. Overall, $50 \%$ of teachers stated that they have doubts about the positive effects of the changes, the same as for Spanish teachers of Social and Legal Sciences, Health Sciences, Sciences, and Engineering and Architecture (Ariza, Quevedo-Blasco, \& Buela-Casal, 2014; Ariza et al., 2013; Quevedo-Blasco, Ariza, \& Buela-Casal, 2015; Quevedo-Blasco \& BuelaCasal, 2017). The results are equal between the proportion of Arts and Humanities teachers that would like to return to the old system and those that would not. The percentage is also comparable between those that think that the quality of Higher Education will improve only slightly and those that think there will be a moderate improvement. Despite the fact that the Arts and Humanities teachers received information that helped them to adapt their subject to the EHEA, they stated that subject planning had been quite difficult for them. It can be noted that, in general, the educational institutions kept teachers informed about the process.

The Arts and Humanities teachers showed moderate satisfaction towards the new European credit, the European Diploma Supplement, the grading system and the accreditation of qualifications. The level of satisfaction towards the new structure of university studies is also moderate. The majority of teaching staff considered that the most appropriate length for degree studies is four years, as has been applied in Spain, unlike in other EHEA countries. Although part of the teaching staff thought that the ideal length would be five years, like some of the previous Spanish degrees. Regarding this, for example, Ramiro-Sánchez, Buela-Casal, and Bermúdez (2016), concluded that there is no improvement with the adaptation to EHEA.

For Master studies giving way to doctoral studies, the majority opted for a length of two years. With regard to doctoral studies there is a wide range of opinions, as part of the teachers would prefer the new postgraduate studies while the other part leaned towards the traditional doctoral studies established before the reform. The results are clear regarding the format of the doctoral thesis, as $82 \%$ chose the traditional thesis, rather than the thesis made up of a collection of published scientific articles. Maybe this is due to the difficulty in publishing in Web of Science or Scopus journals in this area. In fact, in the study by Quevedo-Blasco, Ariza, Bermúdez, and Buela-Casal (2013) it was revealed that the Arts and Humanities teachers do not agree that doctoral students should have articles published in order to defend their thesis.

Another of the EHEA modifications has been to limit the time to carry out the thesis to 
three years (see Jiménez-Ramírez, 2017; JiménezRamírez \& Sevilla Merino, 2017), but the Arts and Humanities teachers thought that it is only possible to finalize it in this period depending on the research area, as research in certain areas requires more time than in others. Likewise, the majority did not think that thesis quality would improve with the new doctoral structure. The fact that the majority did not comment on Doctoral Schools and almost the same proportion of teachers showed indifference towards these institutions could be due to the lack of information regarding their implementation. There was a generally positive opinion towards the creation of the ERA.

The methodology promoted since the introduction of the EHEA is that of the teacher as a guide-mediator and not only as a transmitter of knowledge which has caused moderate effort for Arts and Humanities teachers. Although the majority believed that this methodology would not increase students' learning quality. Likewise, students' level of motivation in the search of their own knowledge is moderate to low and they do not assist tutorials very frequently (see Torrecilla-Sánchez, Burguera-Condon, OlmosMiguélañez, \& Pérez-Herrero, 2018). This is a negative aspect, as motivation is vital for them to have an active role in class (Valle et al., 2015), along with other indicators (Cabanach, SoutoGestal, \& Franco, 2016; Casanova, Cervero, Núñez, Almeida, \& Bernardo, 2018; GarcíaRipa, Sánchez-García, \& Risquez, 2018; Garzón Umerenkova \& Gil Flores, 2017; Vizoso-Gómez \& Arias-Gundín, 2018).

It is positive that the majority of teachers develop competences in their students, although they doubt to what extent doctoral students acquire competences with the new system. However, student assessment is the task that requires most effort by teachers. It is worth noting that competence only based assessment is accepted by only a small group of teachers, maybe because more than $40 \%$ find it hard to assess competences. In this context Cano and Ion (2012) highlighted the negative aspects surrounding this type of assessment, such as an increase in workload, reduction of teaching independence and it depends on the attitude towards the change, on the number of students and on the coordination with other teachers. Also, Abella, Ausín, Delgado, Hortigüela, and Solano (2018) pointed out the necessity for teacher training, Hortigüela Alcalá, Ausín Villaverde, Delgado Benito, and Abella García (2017) informed of the importance of some indicators for education quality in Spain, and Torres-Coronas and Vidal-Blasco (2015) analyze the students and employers perception about the development of digital skills in Higher Education.

The majority of teachers opted for continuous assessment, both for theory and practical classes. Although it has been noted that the amount of passes increases, contents learning is not guaranteed. In general, Arts and Humanities teachers are quite satisfied with the academic results of their students. Nevertheless, they think they were better before EHEA consolidation (38\%) although 35\% think that the results of students from old and new degrees are practically the same.

According to Cáceres-Lorenzo and SalasPascual (2012) there seems to be a link between the development of competences and the increase of bureaucracy. As pointed out by the Arts and Humanities teachers, the excessive bureaucracy, the increase of teaching work and the continual legislative changes are some of the limitations of university policy in Spain. This makes life more difficult for teachers, who have a lot of pressure to carry out administrative tasks and increase their scientific production (Galán, González Galán, \& Román, 2012). Besides, according to the teachers, since the introduction of the EHEA they need more time to prepare classes, so they have less time for research and because of this they would like to be able to invest more time in research tasks. Likewise, a high percentage of teachers would prefer to dedicate less time to administrative tasks. This could be due to the fact that this task is not a high priority for them. Because of this the managers of European organizations for university management and quality maintain that there is a need to make 
university management more professional, while Spanish managers do not think this has priority (Mira Solves et al., 2012).

$65 \%$ of the Arts and Humanities teachers thought that they had sufficient training to teach in the EHEA context. Updating knowledge through lifelong learning is supported by almost all teachers, along with mobility in order to improve as a professional by $67 \%$, which is very positive. Finally, the lack of coordination and resources detected by the Arts and Humanities teachers is also explained by Martín Martín and Bobb Wolff (2011) in qualifications in this field. From the results obtained it can be concluded that Spanish Arts and Humanities teachers are not completely satisfied with the implementation of the EHEA in Spanish university studies. There are certain limitations that should be overcome in order to facilitate the adequate consolidation of the principles of the Bologna Process (see for example, Pozo Muñoz, \& Bretones Nieto, 2015; Quesada Serra, Rodríguez Gómez, \& Ibarra Sáiz, 2017). The solutions proposed by the group could maybe help to improve this reform which will only be successful with the involvement of the educational policy managers, the institutions and all members of the educational community.

\section{Acknowledgments}

This work was supported by the Dirección General de Política Universitaria, Ministerio de Educación, Government of Spain, under Grant EA2011-0048.

\section{References}

Abella, V., Ausín, V., Delgado, V., Hortigüela, D., \& Solano, H. J. (2018). Determinantes de la calidad, la satisfacción y el aprendizaje percibido de la e-formación del profesorado universitario. Revista Mexicana de Investigación Educativa, 23(78), 733-760. http://www.scielo.org.mx/scielo.p hp? script $=$ sci_arttext\&pid $=$ S1405-66662 $018000300733 \& \operatorname{lng}=\mathrm{es} \& \operatorname{tng}=\mathrm{es}$
Ariza, T., Quevedo-Blasco, R., \& Buela-Casal, G. (2014). Satisfaction of Social and Legal Sciences with the introduction of the European Higher Education Area. The European Journal of Psychology Applied to Legal Context, 6(1), 9-16. https://doi.org/10 $.5093 /$ ejpalc2014a2

Ariza, T., Quevedo-Blasco, R., Ramiro, M. T., \& Bermúdez, M. P. (2013). Satisfaction of Health Science teachers with the convergence process of the European Higher Education Area. International Journal of Clinical and Health Psychology, 13(3), 197-206. https://doi.org/10.1016/S1 697-2600(13)70024-3

Bezanilla, M., García Olalla, A., Paños Castro, J., $\&$ Poblete Ruiz, M. (2019). A model for the evaluation of competence-based learning implementation in higher education institutions: Criteria and indicators. Tuning Journal For Higher Education, 6(2), 127-174. https://doi.org/10.18543/tjhe-6(2 )-2019pp127-174

Bologna Declaration. (1999). Joint declaration of the European Ministers of Education. Retrieved from http://www.ehea.info/Uplo ad/document/ministerial_declarations/199

9_Bologna_Declaration_English_553028.p df

Buela-Casal, G., Guillén-Riquelme, A., DíazRomán, A., Carneiro-Barrera, A., \& Quevedo-Blasco, R. (2019). Ranking 2019 de investigación de las universidades públicas españolas. Psicothema, 31(4), 351-362. https://doi.org/10.7334/psicothe ma2019.238

Buela-Casal, G., Guillén-Riquelme, A., RamiroSánchez, T., \& Quevedo-Blasco, R. (2017). Ranking de investigación de las universidades públicas españolas. Revista Iberoamericana de Psicología y Salud, 8(1), 21-35. https://doi.org/10.23923/j.rips.2017. 08.003

Cabanach, R. G., Souto-Gestal, A., \& Franco, V. (2016). Escala de Estresores Académicos para la evaluación de los estresores académicos en estudiantes universitarios. Revista Iberoamericana de Psicología y Salud, 
7(2), 41-50. https://doi.org/10.1016/j.rips.2 016.05 .001

Cáceres-Lorenzo, M. T., \& Salas-Pascual, M. (2012). Valoración del profesorado sobre las competencias genéricas: su efecto en la docencia. Revista Iberoamericana de Psicología y Salud, 3(2), 195-210. https://www.redalyc.org/articulo. oa? $\mathrm{id}=245124456007$

Canet Vélez, O., \& Violant Holz, V. (2014). La función tutorial y las tutorías, vectores pedagógicos en Educación Superior. In J. Rodríguez Torres (Ed.), Experiencias en la adaptación al EEES (pp. 145-156). España: McGraw-Hill.

Cano, E., \& Ion, G. (2012). Prácticas evaluadoras en las universidades catalanas: hacia un modelo centrado en competencias. ESE-Estudios Sobre Educación, 22(1), 155-177. https://www.unav.edu/publicacio nes/revistas/index.php/estudios-sobre-educ acion/article/view/2077

Cano García, E., \& Fernández Ferrer, M. (2016). Competencias de los egresados del Espacio Europeo de Educación Superior: relatos de vida de los nuevos estudiantes universitarios frente a los antiguos licenciados. REDU, Revista de Docencia Universitaria, 14(2), 187-203. htt ps://doi.org/10.4995/redu.2016.5933

Cano García, M. E., Pons Seguí, L., \& Lluch Molins, L. (2018). Análisis de experiencias de innovación docente universitaria sobre evaluación. Profesorado, Revista de Currículum y Formación del Profesorado, 22 (4), 11-32. https://doi.org/10 $.30827 /$ profesorado.v22i4.8392

Cañadas, L., Santos-Pastor, M. L.., \& Castejón, F. J. (2018). Evaluación en la formación inicial: ¿avance o retroceso? Bordón. Revista de Pedagogía, 70 (4), 9-22. https://doi.org/10 .13042 /Bordon.2018.64434

Carneiro-Barrera, A., Ruiz-Herrera, N., \& Díaz-Román, A. (2019). Tesis doctorales en Psicología tras adaptación al Espacio Europeo de Educación Superior. Revista de Investigación en Educación, 17(1), 32-43.
Carrión-Martínez, J. J., Fernández-Martínez, M. M., Pérez-Fuentes, M. C., \& GázquezLinares, J. J. (2018). Specific competencies in social work higher education in the framework of the European higher education area: the perception of future professionals in the Spanish context. European Journal of Social Work, 23(1), 1-13. https://doi.org/10.1080/13691457.20 18.1460717

Casanova, J. R., Cervero, A., Núñez, J. C., Almeida, L. S., y Bernardo, A. (2018). Factors that determine the persistence and dropout of university students. Psicothema, 30(4), 408-414. https://doi.org/10.7334/psi cothema2018.155

Fernández Díaz, M. J., Carballo Santaolalla, R., \& Galán González, A. (2010). Faculty attitudes and training needs to respond the new European Higher Education challenges. Higher Education, 60(1), 101-118. https://doi.org/10.1007/s10 734-009-9282-1

Gaebel, M., \& Zhang, T. (2018). Trends 2018. Learning and teaching in the European Higher Education Area. Bruselas, Bélgica: European University Association (EUA).

Galán, A., González Galán, M. A., \& Román, M. (2012). La irrupción del factor comunitario en el perfil del profesorado universitario. Bordón. Revista de Pedagogía, 64(3), 133-148.

García-Ripa, M., I., Sánchez-García, M. F., \& Risquez, A. (2018). Perfiles motivacionales de elección de estudios en estudiantes universitarios de nuevo ingreso. UniversitasPsychologica, 17(3), 1-12. https:// doi.org/10.11144/Javeriana.upsy17-3.pmee

Garzón Umerenkova, A., \& Gil Flores, J. (2017). Gestión del tiempo y procrastinación en la educación superior. Universitas Psychologica, 16(3), 1-13. https://doi.org/10.11144/Javeri ana.upsy 16-3.gtpe

Hortigüela Alcalá, D., Ausín Villaverde, V., Delgado Benito, V., \& Abella García, V. (2017). Análisis de la importancia de los criterios de evaluación y el reconocimiento académico docente universitario como 
indicadores de la calidad educativa en España. Revista de la Educación Superior, 46(181), 75-87. https://doi.org/10.1016/j.re su.2016.10.002

Jiménez-Ramírez, M. (2017). Los nuevos estudios de doctorado en España: avances y retos para su convergencia con Europa. Revista Iberoamericana de Educación Superior, 8(21), 123-137. https://doi.org/10.22201/iisue.20 072872e.2017.21.217

Jiménez-Ramírez, M., \& Sevilla Merino, D. (2017). El doctorado en España: estudio e implicaciones dentro del espacio europeo de la educación superior. Revista Lusófona de Educação, 35 (35), 51-65. https://doi.org/10 $.24140 /$ issn. 1645-7250.rle35.03

Leví Orta, G., \& Ramos Méndez, E. (2012). Mapas de conceptos de los subcomponentes de las competencias en los nuevos grados universitarios. Enseñanza $\mathcal{E}$ Teaching, 30 (2), 23-43. https://dialnet.unirioja.es/servlet/art iculo? codigo $=4091423$

Lisbon European Council. (2000). Presidency conclusions. http://www.europarl.europa.eu /summits/lis1_en.htm

Martín, D., \& García García, M. (2018). Transformación del modelo educativo en el aprendizaje y desarrollo competencial. Estudio de caso. Bordón. Revista de Pedagogía, 70 (4), 103-119. https://doi.org/1 0.13042/Bordon.2018.60992

Martín Martín, P., \& Bobb Wolff, L. (2011). La implantación de los nuevos grados: propuestas de mejora. Revista de Educación, (356), 703-715. https://doi.org/10-4438/19 88-592X-RE-2010-356-120

Martínez Clares, P., \& González Morga, N. (2018). Las competencias transversales en la universidad: propiedades psicométricas de un cuestionario. Educación XX1, 21(1), 231-262. https://10.5944/educXX1.15662

Martínez Clares, P., \& González Morga, N. (2019). El dominio de competencias transversales en Educación Superior en diferentes contextos formativos. Educação e Pesquisa, 45, e188436. https://http://dx.doi. org/10.1590/S1678-4634201945188436
Ministerial Conference Bucharest. (2012). Mobility for Better Learning. Mobility strategy 2020 for the European Higher Education Area (EHEA). http://www.ehea.info/media.ehea .info/file/2012_Bucharest/39/2/2012_EHE A_Mobility_Strategy_606392.pdf

Ministerio de Educación. (2011). Estrategia Universidad 2015. Contribución de las universidades al progreso socioeconómico español 2010-2015. http://www.mecd.gob.e s/dms-static/a8c5f36e-f467-4e87-b749-352 9cc3b856b/2011-estrategia-universidad-20 15-pdf.pdf

Ministerio de Educación, Cultura y Deporte (2016). Estrategia para la Internacionalización de las Universidades Españolas 2015-2020. Madrid, España: Secretaría General Técnica. Subdirección General de Documentación y Publicaciones. https://sede.educacion.gob. es/publiventa/descarga.action?f_codigo_ag $\mathrm{c}=18182$

Mira Solves, J. J., Galán Vallejo, M., Van Kemenade, E., Marzo Campos, J. C., Blaya Salvador, I., \& Pérez Jover, M. V. (2012). Retos para el gobierno de las universidades en el marco del EEES. Revista de Educación, (357), 445-465. https://doi.org/10-4438/19 88-592X-RE-2010-357-068

Moreno-Murcia, J. A., Pintado, R., Huéscar, E., \& Marzo, J. C. (2018). Estilo interpersonal controlador y percepción de competencia en educación superior. European Journal of Education and Psychology, 11(1), 33-45. htt ps://doi.org/10.30552/ejep.v11i1.184

Palma i Muñoz, M. (2019). Movilidad y dimensión social: fundamentos del Espacio Europeo de Educación Superior y el proceso de Bolonia Resumen estructurado. ACE: Arquitectura, Ciudad y Entorno, 14(40), 231-246. https://doi.org/10.5821/ace.14.40 .6770

Pozo Muñoz, C., \& Bretones Nieto, B. (2015). Dificultades y retos en la implantación de los títulos de grado en las universidades españolas. Revista de Educación, (367), 147-172. https://doi.org/10.4438/1988-592 X-RE-2015-367-286 
Quesada Serra, V., Rodríguez Gómez, G., \& Ibarra Sáiz, M.S. (2017). Planificación e innovación de la evaluación en educación superior: la perspectiva del profesorado. Revista de Investigación Educativa, 35(1), 53-70. https://doi.org/10.6018/rie.35.1.239 261

Quevedo-Blasco, R., Ariza, T., Bermúdez, M. P., \& Buela-Casal, G. (2013). Actitudes del profesorado universitario español: formato de tesis doctorales, docencia e investigación. Aula Abierta, 41(2), 5-12. https://dialnet.unirioja.es/servlet/arti culo? codigo $=4239027$

Quevedo-Blasco, R., Ariza, T., \& Buela-Casal. G. (2015). Evaluación de la satisfacción del profesorado de Ciencias con la adaptación al Espacio Europeo de Educación Superior. Educación XX1, 18(1), 45-70. https://doi.or $\mathrm{g} / 10.5944 /$ educxx1.18.1.12311

Quevedo-Blasco, R., \& Buela-Casal. G. (2017). Influence of the implementation of the European Higher Education area on Engineering and Architecture university teachers. Dyna (Spain), 92, 333-338. https: //doi.org/10.6036/8045

Ramiro-Sánchez, T., Buela-Casal, G., \& Bermúdez, M. P. (2016). University Qualification in Psychology in EHEA: Comparison Between Spanish Grado and Licenciatura Qualification. Revista de Psicodidáctica, 21(1), 175-189. https://doi.o rg/10.1387/RevPsicodidact.13923

Rodríguez-Fernández, A., Ramos-Díaz, E., Fernández-Zabala, A., Goñi, E., Esnaola, I., \& Goñi, A. (2016). Contextual and psychological variables in a descriptive model of subjective well-being and school engagement. International Journal of Clinical and Health Psychology, 16(2), 166-174. http s://doi.org/10.1016/j.ijchp.2016.01.003

Royal Decree [Decreto Real] 1044/2003, de 1 de agosto, por el que se establece el procedimiento para la expedición por las universidades del Suplemento Europeo al Título (BOE n. ${ }^{\circ} 218$, de 11 de septiembre de 2003). https://www.boe.es/buscar/pdf/20 03/BOE-A-2003-17310-consolidado.pdf
Royal Decree [Decreto Real] 1125/2003, de 5 de septiembre, por el que se establece el sistema europeo de créditos y el sistema de calificaciones en las titulaciones universitarias de carácter oficial y validez en todo el territorio nacional (BOE n. ${ }^{\circ} 224$, de 18 de septiembre de 2003). http://www.eees.es/pdf/RD_Cred itos_Sistema_calificaciones.pdf

Royal Decree [Decreto Real] 1393/2007, de 29 de octubre, por el que se establece la ordenación de las enseñanzas universitarias oficiales (BOE n. ${ }^{\circ} 260$, de 30 de octubre de 2007). http://www.eees.es/pdf/RD_201393 -2007.pdf

Royal Decree [Decreto Real] 99/2011, de 28 de enero, por el que se regulan las enseñanzas oficiales de doctorado (BOE n. ${ }^{\circ}$ 35, de 10 de febrero de 2011). http://www.boe.es/boe/di as/2011/02/10/pdfs/BOE-A-2011-2541.pdf

Sandoval, J. S., \& Pérez-Zapata, D. I. (2017). Concepción de aprendizaje en estudiantes universitarios de la Carrera de Psicología del extremo norte de Chile. Universitas Psychologica, 16(2), 1-11. https://doi.org/10 .11144/Javeriana.upsy16-2.caeu

Torrecilla-Sánchez, E.-M., Burguera-Condon, J.-L., Olmos-Miguélañez, S., \& PérezHerrero, M.-H. (2018). Psychometric analysis of a scale for assessing specific competences in tutoring and educational guidance. Cultura y Educación, 30(1), 38-70. https://doi.org/10.1080/11356405.2 017.1416742

Torres-Coronas, T., \& Vidal-Blasco, M.A. (2015). Percepción de estudiantes y empleadores sobre el desarrollo de competencias digitales en la Educación Superior. Revista de Educación, (367), 63-90. https://doi.org/10.4438/1988-592XRE-2015-367-283

Valle, A., Regueiro, B., Rodríguez, S., Piñeiro, I., Freire, C., Ferradás, M., \& Suárez, N. (2015). Perfiles motivacionales como combinación de expectativas de autoeficacia y metas académicas en estudiantes universitarios. European Journal of Education and Psychology, 8(1), 1-8. https ://doi.org/10.1016/j.ejeps.2015.10.001 
Raúl Quevedo-Blasco, Gualberto Buela-Casal.

Vargas, M. M., \& Montero, E. (2016). Factores que determinan el rendimiento académico en Matemáticas en el contexto de una universidad tecnológica: aplicación de un Modelo de Ecuaciones Estructurales. Universitas Psychologica, 15(4), 1-11. https:/ /doi.org/10.11144/Javeriana.upsy15 -4.fdra

Vizoso-Gómez, C., \& Arias-Gundín, O. (2018). Resiliencia, optimismo y burnout académico en estudiantes universitarios. European Journal of Education and Psychology, 11(1), 47-59. https://doi.org/10. 30552/ejep.v11i1.185

\section{Notes}

* $\quad$ Research article. 